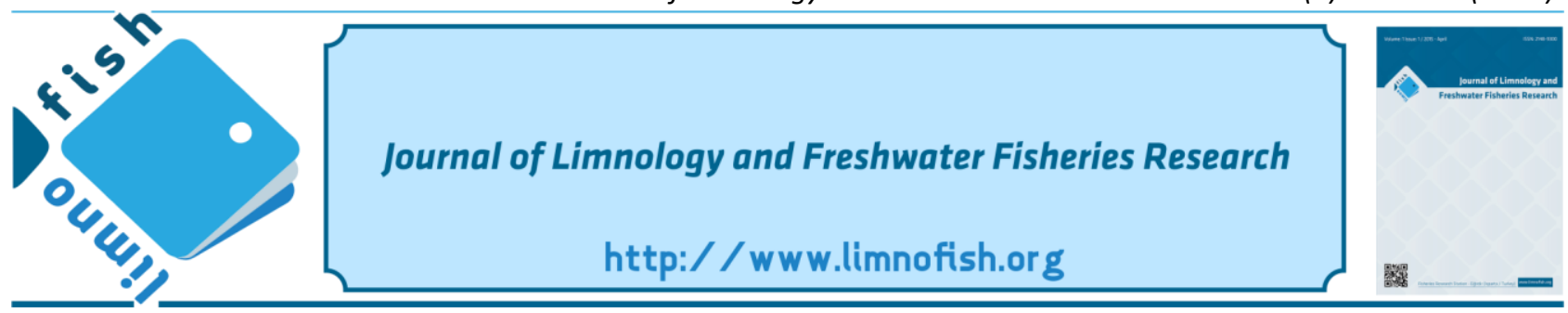

\title{
Effects of Environmental Parameters on the Seasonal Distribution of Phytoplankton in the Shallow Lake Ketence, Turkey
}

\author{
Hatice TUNCA $^{1}$ (i), Kübra KÖSE ${ }^{1}$ (D), Tuğba ONGUN SEVINDIK ${ }^{1}$ iD \\ ${ }^{1}$ Sakarya University, Faculty of Arts and Science, Department of Biology, 54187, Sakarya, Turkey
}

\section{A B STR ACT}

The seasonal distribution of the phytoplankton and their relationship with environmental parameters of Lake Ketence was studied in monthly intervals in two stations between October 2016 and September 2017. A total of 93 taxa belonging to 8 divisions were identified, and 11 taxa belonging to 4 different divisions (Chlorophyta, Bacillariophyta, Euglenozoa, Miozoa) dominated the phytoplankton in different periods of the study. Main nutrients $\left(\mathrm{NO}_{3}-\mathrm{N}, \mathrm{NO}_{2}-\mathrm{N}\right.$, TP, Si), some other parameters (T, EC, secchi disk depth), and organic content of the lake had strong impacts on the distribution of phytoplankton assemblages. Although biomass values varied and indicated very good to bad water quality during the studied period, especially the prevalence of chlorophytes such as Tetraedron minimum which prefer high nutrient and euglenoids such as Euglena clavata, Euglena rubra, Phacus longicauda and Trachelomonas oblonga that grew extremely well under high organic content has confirmed that Lake Ketence is eutrophic.

\section{ARTICLE INFO}

\section{RESEARCH ARTICLE}

Received : 25.12 .2020

Revised :09.02.2021

Accepted : 22.02 .2021

Published : 30.12 .2021

DOI:10.17216/LimnoFish. 846991

* CORRESPONDING AUTHOR

htunca@sakarya.edu.tr

Phone: +90. 2642956128

Keywords: Community ecology, phytoplankton, shallow lake

\begin{abstract}
Sı̆̆ Ketence Gölü’nde (Türkiye) Fitoplanktonun Mevsimsel Dağılımına Çevresel Parametrelerin Etkileri
Öz: Ketence Gölü'nün fitoplanktonunun mevsimsel dağılımı ve çevresel parametreleriyle ilişkisi Ekim 2016 ve Eylül 2017 arasında iki istasyonda aylık aralıklarla çalışılmıştır. 8 divizyoda toplam 93 takson tespit edilmiştir. 4 farklı divizyoda (Chlorophyta, Bacillariophyta, Euglenozoa, Miozoa) toplam 11 takson çalışmanın farklı dönemlerinde fitoplanktona hakim olmuştur. Gölün ana besin maddeleri ( $\mathrm{NO}_{3}-\mathrm{N}, \mathrm{NO}_{2}-\mathrm{N}, \mathrm{TP}, \mathrm{Si}$ ), diğer bazı parametreler (Sicaklık, elektriksel iletkenlik, secchi diski derinliği) ve organik içeriğinin fitoplankton topluluklarının dağılımı üzerinde güçlü etkileri olmuştur. Her ne kadar biyokütle değerleri, incelenen dönem boyunca çok iyi ile kötü su kalitesi arasında değişiklik göstermiş olsa da, özellikle yüksek besin tuzu tercih eden Tetraedron minimum gibi chlorofitlerin varlığı ve yüksek organik madde varlığında hızla gelişebilen Euglena clavata, Euglena rubra, Phacus longicauda ve Trachelomona oblonga gibi öglenoidlerin varlı̆̆ Ketence Gölü’nün ötrofik olduğuna işaret etmektedir.
\end{abstract}

Anahtar kelimeler: Komunite ekolojisi, fitoplankton, sı̆̆ göl

How to Cite

Tunca H, Köse H, Ongun Sevindik T. 2021. Effects of Environmental Parameters on the Seasonal Distribution of Phytoplankton in the Shallow Lake Ketence, Turkey LimnoFish. 7(3): 250-259. doi: 10.17216/LimnoFish.846991

\section{Introduction}

Lakes are exposed to various adverse effects including pollution, depletion of water resources, and eutrophication. These impacts have caused deterioration in these ecosystems (Fakıoglu and Demir 2011). The determination of the general limnological status of an aquatic ecosystem is the first step in management plans for its protection and improvement. For this reason, the Water Framework Directive (WFD) was created to assess the ecological quality of surface waters through the analysis of various characteristics of aquatic flora and fauna and to declare management plans in European countries (EC 2009). Five biological quality elements including phytoplankton are currently being employed by the WFD (EC 2000) for ecological status assessment. The intraspecific and interspecific competitions in the community, the different nutrient intake capacity of each species, and their different responses to physical (eg., light, mixing events) and chemical (eg., nutrients, $\mathrm{pH}$, salinity) variables have caused different changes in the phytoplankton community structure throughout the year (Mortensen et al. 1992; Carpenter and Kitchell 1993; NaselliFlores 2000; Reynolds 2006). Thus, it is possible to obtain inferences about the changes in the physicochemical and biological conditions of the lake over time through the changes observed in 
phytoplankton (Elser et al. 2000; Nevers and Whitman 2010).

Small and shallow lakes are ecosystems that have roles in controlling regional climate as well as being important in global carbon and nutrient cycles (Cole et al. 2007; Harrison et al. 2009). Moreover, many shallow lakes exhibit a large habitat diversity (Padisák et al. 2003) and have rich algal flora (Borics et al. 2003). However, as a consequence of their small water volume, shallow lakes are more affected by human impact and drought events (Padisák et al. 2003; da Costa et al. 2016). Several studies have been done on the composition, abundance, and species diversity of phytoplankton of shallow lakes (Borics et al. 2003; Padisák et al. 2003; da Costa et al. 2016; Borics et al. 2012). In recent years, the seasonal distribution of phytoplankton community of shallow lakes was also studied in Turkey (Çelik and Ongun 2006; Taş and Gönülol 2007; Yerli et al. 2012; Sevindik and Çelik 2014; Demir et al. 2014; Sevindik et al. 2017). However, the phytoplankton composition or abundance of Lake Ketence in the Marmara Basin, which is a shallow lake, has not been studied yet. In this study, we described the seasonal patterns of the phytoplankton composition and biomass concerning physical and chemical factors to determine the phytoplankton community structure in Lake Ketence, Turkey. Thus, this study aims (i) to assess the general trophic state of the lake using phytoplankton biomass and composition, and (ii) to define the most important environmental factor(s) driving the distribution of phytoplankton assemblages.

\section{Materials and Methods}

Lake Ketence, which is in the Kartepe District of Kocaeli, is located $17 \mathrm{~km}$ east of Izmit city center (X: 40763593, Y: 30115950) (Figure 1). Lake Ketence is an artificial set lake built-in 1980 for irrigation of agricultural lands in Kirazoğlu and Ketence villages. The altitude of the lake is $55 \mathrm{~m}$. The length and width of the lake are $1.5 \mathrm{~km}$, and $0.3 \mathrm{~km}$, respectively, and its average depth is $2 \mathrm{~m}$.

Phytoplankton samplings were conducted with monthly intervals at two monitoring stations of the lake between October 2016 and September 2017. The distance between the sampling stations was $1 \mathrm{~km}$. One of the selected stations was determined at the deepest point $(3 \mathrm{~m})$ of the lake. Samples were collected from $50 \mathrm{~cm}$ below the surface. In the field, samples were placed in $250 \mathrm{~mL}$ bottles and fixed with Lugol's solution. Counting of cells was performed according to Utermöhl (1958) with an Olympus IX81 inverted microscope. The algal species were identified according to mostly used identification books in phytoplankton. Algal species were identified according to Huber-Pestalozzi (1941, 1950, 1961, 1962, 1969, 1972, 1975, 1982, 1983), Round et al. (1990), Kramer and Lange-Bertalot (1986, 1991a, 1991b, 1999), Krammer (2003), Sims (1996), John et al. (2003), Komarek and Anagnostidis (2008). The taxonomy of algae was checked according to Guiry and Guiry (2020). Phytoplankton biovolume was calculated from the number of cells and cell size measurements using appropriate geometric formulas (Sun and Liu 2003). Cell size measurements were performed for all taxa in all samples by measuring at least 20 individuals (Brierley et al. 2007).

Sampling for chemical analyses and the measurement of physical variables were carried out in conjunction with phytoplankton collection. Specific conductance (EC), $\mathrm{pH}$, dissolved oxygen (DO), and water temperature ( $\mathrm{T}$ ) were measured at 50 $\mathrm{cm}$ below the surface at two stations using the YSI Proplus water quality instrument. Water transparency was measured using a secchi disk. For the analysis of chemical variables, samples were collected $50 \mathrm{~cm}$ below the surface. Concentrations of total phosphorus (TP), orthophosphate $\left(\mathrm{PO}_{4}-\mathrm{P}\right)$, nitratenitrogen $\left(\mathrm{NO}_{3}-\mathrm{N}\right)$, nitrite-nitrogen $\left(\mathrm{NO}_{2}-\mathrm{N}\right)$, and soluble silica $(\mathrm{Si})$ were determined spectrophotometrically according to Strickland and Parsons (1972) and Technicon Industrial Methods (1977a, 1977b).

A total of 24 samples for phytoplankton and environmental variables were used to maintain the statistical analyses. An analysis of variance (one-way ANOVA) test was applied to data for determining the statistical differences in environmental variables, phytoplankton biomass, and species richness among two stations using SPSS 20.0 software. Physical and chemical variables were logarithmically transformed for correlation analyses. Spearman correlations between the environmental parameters, phytoplankton biomass, and species richness were also determined using the SPSS 20.0 software. Phytoplankton species occurring more than once with biomass larger than $20 \%$ were used in the statistical analyses. To check the suitability of canonical correspondence analysis (CCA), gradient length was measured at first by detrended correspondence analysis (DCA). Since the gradient was 2.37 SD units long, the linear method (RDA) was carried out using CANOCO software (Ter Braak and Smilauer 2002). To determine the relationship between the relative biomass of dominant phytoplankton, sampling stations, and environmental variables, RDA was carried out on the log-normal transformed abundance data. Statistical significance of the environmental predictor variables was assessed by 999 restricted Monte Carlo permutations. To analyze the 
relationship between the relative biomass of phytoplankton and 10 environmental variables (T, pH, EC, DO, $\mathrm{NO}_{3}-\mathrm{N}, \mathrm{NO}_{2}-\mathrm{N}, \mathrm{TP}, \mathrm{PO}_{4}-\mathrm{P}$, $\mathrm{Si}$, secchi disk depth), we performed RDA using relative biomass values of the 11 dominant phytoplankton taxa in the lake. RDA was performed, initially on the whole environmental and phytoplankton datasets. Forward selection indicated that 7 of the 10 environmental variables made a significant contribution to the variance in the phytoplankton data.

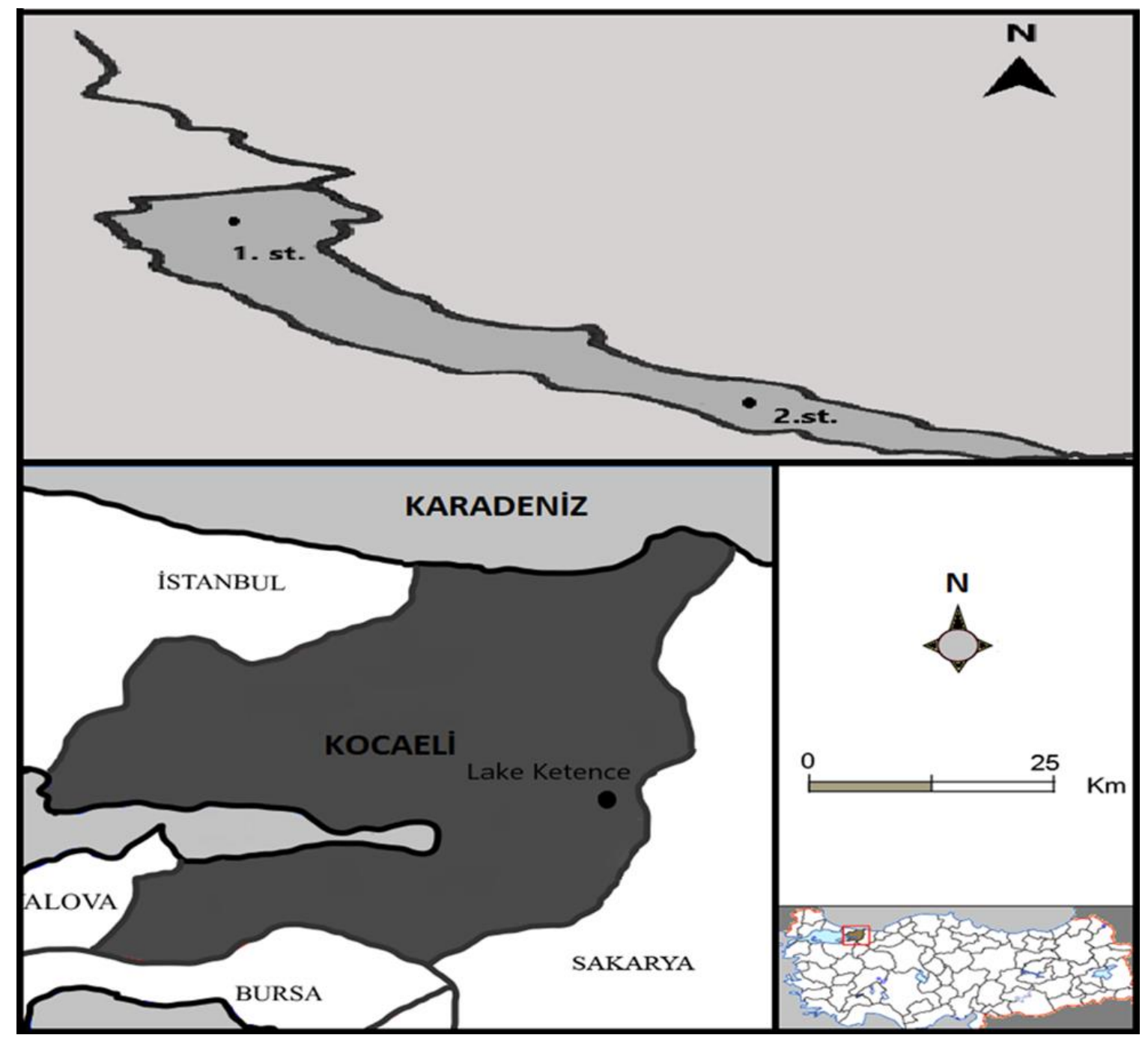

Figure 1. Lake Ketence and location of sampling stations

\section{Results}

\section{Environmental variables}

The mean and standard deviations of environmental parameters measured in two stations of Lake Ketence were listed in Table 1. The minimum temperature was recorded at both stations in December 2016. The EC values ranged from 288.1 $\mu \mathrm{S} \mathrm{cm} \mathrm{cm}^{-1}$ to $523 \mu \mathrm{S} \mathrm{cm}{ }^{-1}$, respectively and higher values were recorded in spring and summer months at both stations. $\mathrm{pH}$ values were measured higher at the 1st station ( $\mathrm{f}=4.42, \mathrm{p}<0.05)$ during the studied period. Higher $\mathrm{pH}$ and DO values were recorded during the winter months, while secchi disk depth values were high during spring at both stations. TP and $\mathrm{NO}_{2}-\mathrm{N}$ values were high during summer, while $\mathrm{NO}_{3}-\mathrm{N}$ values were high during fall, and $\mathrm{Si}$ values were high during fall and winter in the stations. The measured environmental parameters were not significantly different among stations except for $\mathrm{pH}$. According to Spearman correlations, T, EC, TP, and $\mathrm{NO}_{2}-\mathrm{N}$ were positively correlated with each other $(\mathrm{p}<0.01)$, while all of them were negatively correlated with $\mathrm{pH}, \mathrm{DO}, \mathrm{NO}_{3}-\mathrm{N}$, and $\mathrm{Si}(\mathrm{p}<0.05)$. 
Table 1. The mean and standard deviation (SD) of environmental variables measured in two stations of Lake Ketence *

\begin{tabular}{|c|c|c|}
\hline \multirow{2}{*}{ Variable } & 1st station & 2nd station \\
\hline & Mean \pm SD & Mean \pm SD \\
\hline $\mathbf{T}\left({ }^{\circ} \mathrm{C}\right)$ & $17.38 \pm 8.44$ & $18.60 \pm 8.42$ \\
\hline pH & $8.67 \pm 0.18$ & $8.51 \pm 0.17$ \\
\hline $\mathrm{EC}\left(\mu \mathrm{Scm}^{-1}\right)$ & $398.25 \pm 85.20$ & $411.06 \pm 77.15$ \\
\hline DO $\left(\mathrm{mgL}^{-1}\right)$ & $6.60 \pm 3.84$ & $6.37 \pm 3.89$ \\
\hline Secchi disk (cm) & $84.16 \pm 33.69$ & $72.50 \pm 23.40$ \\
\hline $\mathrm{NO}_{3}-\mathrm{N}\left(\mathrm{mgL}^{-1}\right)$ & $0.43 \pm 0.44$ & $0.39 \pm 0.43$ \\
\hline $\mathrm{NO}_{2}-\mathrm{N}\left(\mathrm{mgL}^{-1}\right)$ & $0.01 \pm 0.01$ & $0.01 \pm 0.01$ \\
\hline $\mathrm{PO}_{4}-\mathrm{P}\left(\mathrm{mgL}^{-1}\right)$ & $0.02 \pm 0.02$ & $0.02 \pm 0.01$ \\
\hline $\mathbf{T P}\left(\mathrm{mgL}^{-1}\right)$ & $0.06 \pm 0.05$ & $0.06 \pm 0.06$ \\
\hline $\mathrm{Si}\left(\mathrm{mgL}^{-1}\right)$ & $0.01 \pm 0.01$ & $0.01 \pm 0.01$ \\
\hline
\end{tabular}

*T: water temperature, EC: specific conductance, DO: dissolved oxygen, $\mathbf{N O}_{3}-\mathbf{N}$ : nitrate-nitrogen, $\mathrm{NO}_{2}-\mathrm{N}$ : nitrite-nitrogen, PO4-P: orthophosphate, TP: total phosphorus, Si: soluble silica.

\section{Phytoplankton}

A total of 93 taxa in 8 divisions were described in Lake Ketence. As shown in Figure 2, Bacillariophyta, Euglenozoa, Miozoa, and Chlorophyta dominated at least once during the sampling period in both of the stations. Species richness ranged between 10 and 37 in the lake during the studied periods. Phytoplankton biomass was recorded minimum of $0.0002 \mathrm{~g} \mathrm{~L}^{-1}$ and a maximum of $0.02 \mathrm{~g} \mathrm{~L}^{-1}$. These values indicated that the ecological quality of the lake varies between very good and bad water quality in different periods according to Sondergaard et al. (2005). Species richness and phytoplankton biomass values did not differ among the stations $(p>0.05)$. Species richness was negatively correlated with secchi disk depth $(\mathrm{r}=-0.52, \mathrm{p}<0.01)$ and $\mathrm{NO}_{3}-\mathrm{N}(\mathrm{r}=-0.43, \mathrm{p}<0.05)$. Phytoplankton biomass was negatively correlated with $\mathrm{NO}_{3}-\mathrm{N}(\mathrm{r}=-0.67, \mathrm{p}<0.01)$ and $\mathrm{Si}(\mathrm{r}=-0.55$, $\mathrm{p}<0.01)$, while positively correlated with TP $(\mathrm{r}=0.46, \mathrm{p}<0.05)$.

a
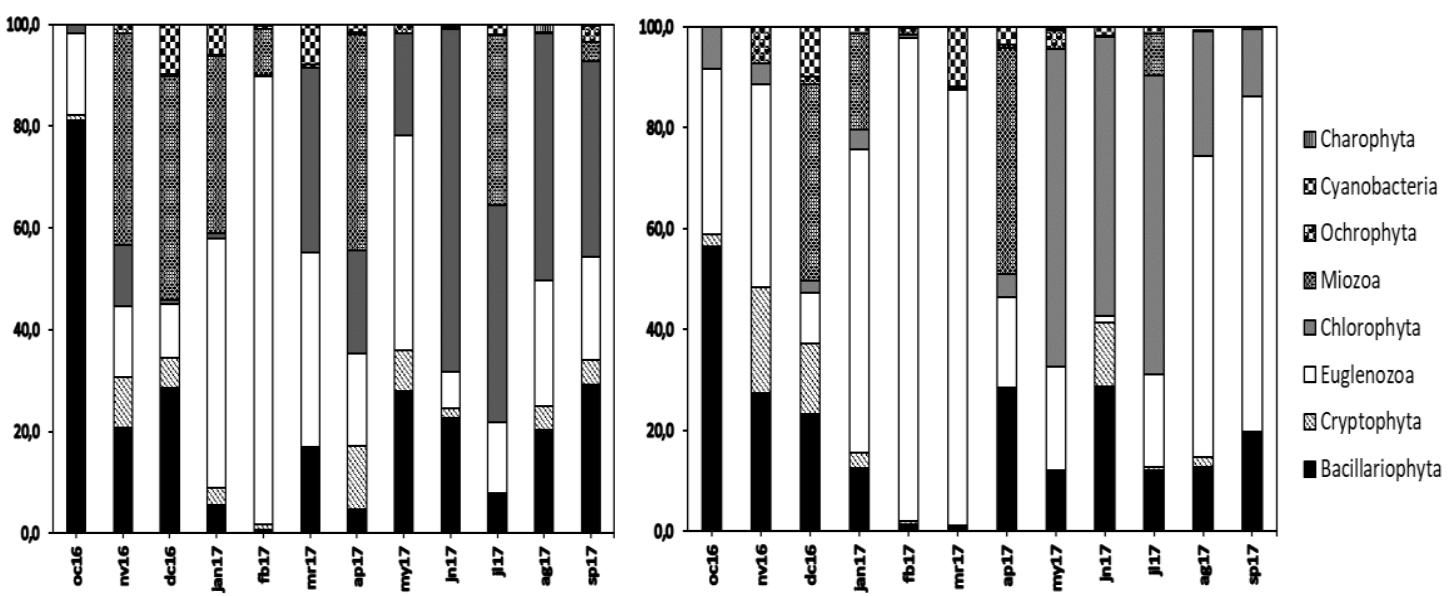

Figure 2. Relative frequency (\%) of each phytoplankton taxonomical group according to biomass values* * a) in 1st station, b) in 2nd station of Lake Ketence.

11 phytoplankton taxa constituted $>20 \%$ of the total biomass in at least one sample. The relative frequency of dominant taxa obtained at two stations of Lake Ketence for each month was given in Figure 3. At the 1st station, Tetraëdron minimum (Braun)
Hansgirg was abundant between March and September 2017 and prevailed among the phytoplankton especially in the summer months. Pantocsekiella ocellata (Pantocsek) Kiss \& Ács were abundant in October and November 2016, and June 
2017, while Apocalathium aciculiferum (Lemmermann) Craveiro, Daugbjerg, Moestrup \& Calado was dominant in December 2016. On the other hand, Naiadinium polonicum (Woloszynska) Carty was an important component of phytoplankton in November 2016, January, April, and July 2017, while Euglena rubra Hardy dominated in phytoplankton during January and February 2017. Moreover, Trachelomonas volvocina (Ehrenberg) Ehrenberg, Trachelomonas oblonga Lemmermann, Euglenaria clavata (Skuja) Karnkowska \& Linton, and Ulnaria acus (Kützing) Aboal were an important component of phytoplankton in the 1st station. At the 2nd station, T. minimum dominated during May and July 2017. Phacus longicauda (Ehrenberg) Dujardin was abundant in September, January, and March 2017, while E. rubra dominated in phytoplankton between January and March 2017, and August 2017. T. volvocina and Cryptomonas erosa Ehrenberg prevailed among the phytoplankton from October to December 2016, while A. aciculiferum was dominant in December 2016, and $N$. polonicum was dominant in April 2017. Moreover, P. ocellata was abundant in the spring months.

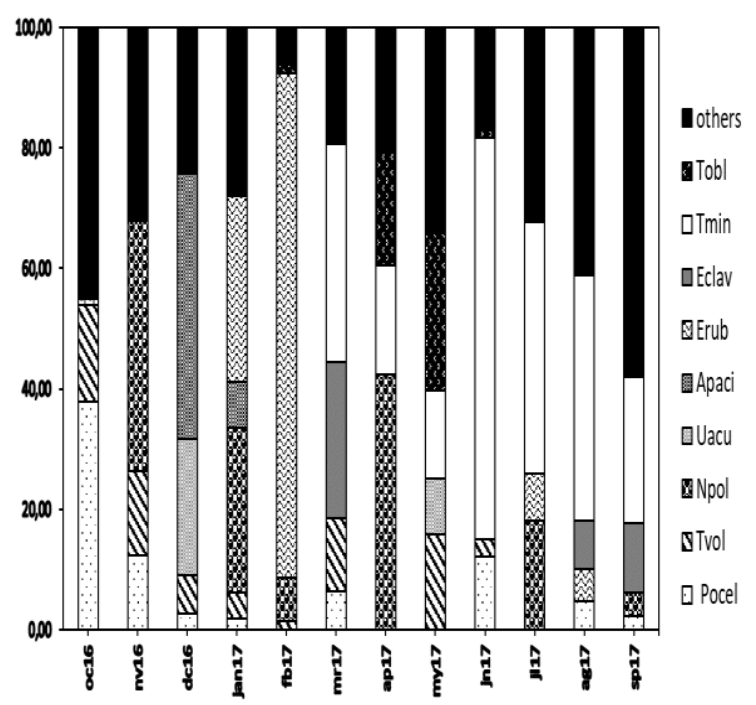

$b$

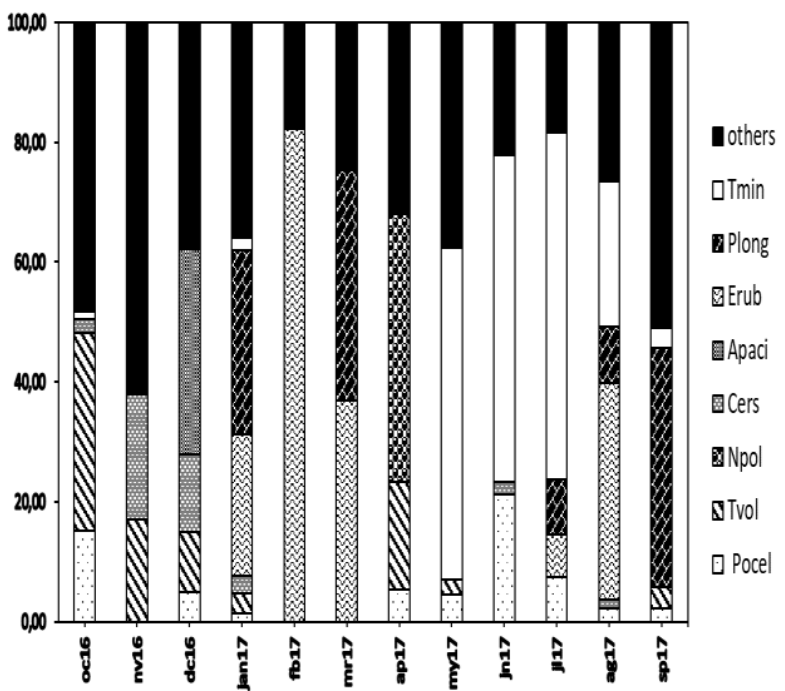

Figure 3. Relative frequency (\%) of each dominant phytoplankton taxa according to biomass values*

a) in 1st station, b) in 2nd station of Lake Ketence (Tmin: Tetraëdron minimum, Pocel: Pantocsekiella ocellata, Apaci: Apocalathium aciculiferum, Npol: Naiadinium polonicum, Erub: Euglena rubra, Tvol: Trachelomonas volvocina, Tobl: Trachelomonas oblonga, Eclav: Euglenaria clavata, Uacu: Ulnaria acus, Plong: Phacus longicauda, Cers: Cryptomonas erosa)

Environmental parameters and
phytoplankton
The results of RDA using only 7 variables are
illustrated in Figure 4 . The eigen values of RDA axis
$1(0.20)$ and axis $2(0.17)$, account for $37.2 \%$ of the
cumulative variance in the hytoplankton data. The
phytoplankton - environmental correlations of RDA
axis 1 and 2 are high and the first two axes account
for $75.2 \%$ of the variance in the phytoplankton -
environmental relationships. The ordination of the
RDA indicated that predictor variables
(environmental factors) affect the distribution of
phytoplankton assemblages in the stations of the

Lake Ketence. As shown in Figure 4, the fall and winter months (October, November, December, January) were distributed in the positive part of the first axis. On the other hand, other months were located in the opposite part. Species such as A. aciculiferum, C. erosa, $N$. polonicum, U. acus, and T. volvocina were related to high $\mathrm{Si}$ and $\mathrm{NO}_{3}-\mathrm{N}$, while $P$. ocellata was correlated with secchi disk depth. On the other hand, T. minimum was related to high $\mathrm{TP}, \mathrm{EC}$, and T. E. clavata was correlated with $\mathrm{NO}_{2}-\mathrm{N}$, while T. oblonga, E. rubra, and P. longicauda were correlated with low nutrients. 


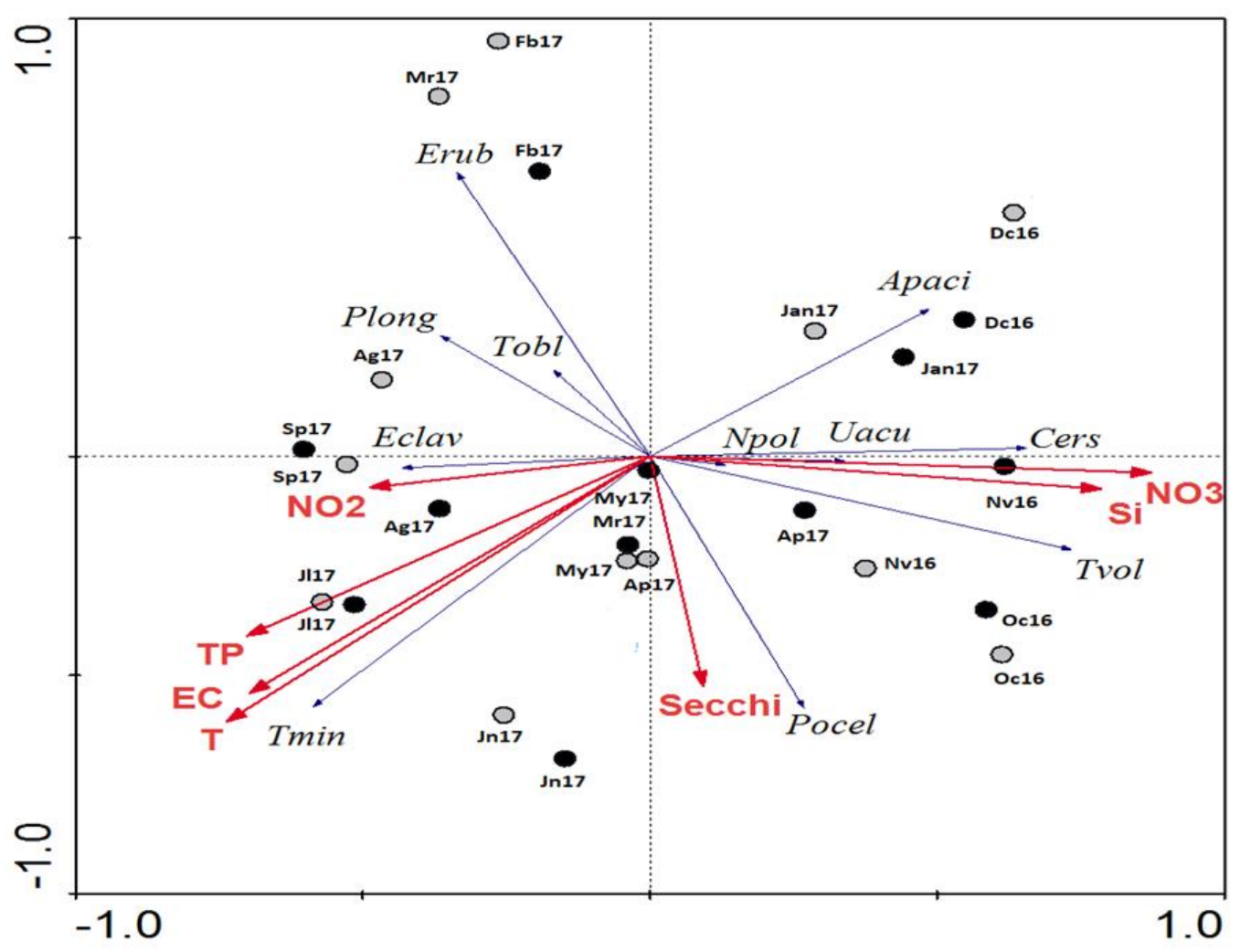

Figure 4. Ordination of the samples corresponding to the different sampling periods and stations, scores of phytoplankton species biomass and environmental variables, along the redundancy analysis axes*

*Environmental variables: T: Temperature, EC: specific conductance, Secchi: Secchi disk depth, TP: total phosphorus, $\mathbf{N O}_{3}-\mathbf{N}$ : nitrate-nitrogen, $\mathbf{N O}_{2}-\mathbf{N}$ : nitrite-nitrogen, Si: soluble silica) (dark dot: 1st station, grey dot: 2 nd station) (Abbreviations of species names were given in Figure 3).

\section{Discussion}

In shallow lakes, as a consequence of intense sediment-water interaction (Scheffer 1998), nutrient cycling is faster and may support much higher productivity (Schindler and Scheuerell 2002; Mehner et al. 2005). Although the biomass values varied in different periods of the year in Lake Ketence, it was observed that they were generally high especially in summer months where TP values were high. Similarly, several studies have confirmed the effect of TP on phytoplankton biomass (Phillips et al. 2008; Jeppesen et al. 2002; Cooke et al. 2016).

In the studied lake, two diatoms (Bacillariophyta) species; P. ocellata during fall and spring, and $U$. acus in winter, were dominant. Their dominancy between fall and spring months were reported in many other shallow lakes studied in Turkey (eg., Taş et al. 2002; Taş and Gönülol 2007; Atıc1 et al. 2010; Yılmaz and Güleçal 2012). Members of this group are unable to regulate their buoyancy and prefer wellmixed water columns (Reynolds 2006). Hence, the development of small, fast-growing, planktonic Pantocsekiella, which are C-strategy species (Reynolds 1993; Seip and Reynolds 1995), was favored under mixing conditions of fall and spring.
During spring, secchi disk values were high and, in the RDA diagram, $P$. ocellata as a matter of course correlated well with secchi disk values. Besides, both species are sensitive to nutrient depletion (Reynolds et al. 2002; Padisák et al. 2009) and preferred the Si and $\mathrm{NO}_{3}-\mathrm{N}$ rich conditions of these months. Moreover, C. erosa (Cryptophyta) increased its biomass in phytoplankton during the late fall and early winter. In the RDA diagram, this species occurred near the $\mathrm{NO}_{3}-\mathrm{N}$ and $\mathrm{Si}$ values which increased in fall and winter. The seasonality of cryptophytes was mainly affected by temperature and light intensity (Barone and Naselli-Flores 2003). Moreover, these algae can migrate vertically (Clegg et al. 2007) to avoid the high light intensity (Graham and Wilcox 2000) and to stay at optimal nutrient conditions (Giroldo and Vieira 1999; Longhi and Beisner 2009) and low zooplankton grazing pressure (Padisák 2004). In Lake Ketence, it seems that low light requirement and possibly low zooplankton feeding pressure during late fall and early winter were the key factors in the success of this species during that period. Dinoflagellate (Miozoa) species such as A. aciculiferum and $N$. polonicum were also found in fall and winter months where TP values were low, however, $\mathrm{Si}$ and $\mathrm{NO}_{3}-\mathrm{N}$ values were high, 
as confirmed by RDA. Because of their capacity for luxury consumption of phosphorus (Pollingher 1988) and the ability to migrate vertically through the whole water column in search of nutrients (Lindenschmidt and Chorus 1998), dinoflagellates endured low phosphorus levels during those months in this lake. Moreover, with their active locomotion, they can select the layer which is optimal for their photosynthesis (Whittington et al. 2000; Grigorszky et al. 2003).

As shown in the RDA, the prevalence of Euglenozoa members (E. clavata, E. rubra, $P$. longicauda, and T. oblonga) during early spring where nutrient levels were low, can be explained by the higher organic contents of the lake during that period. Members of this group were known as heterotrophic feeders and grew extremely well under high organic content (Stevenson et al. 1996; Borics et al. 2003). It is thought that the fertilization activities carried out in the agricultural areas around the lake in this period, may affect the organic matter content of the lake. The second increase in biomass of this group was observed in the stable late summer period where the $\mathrm{NO}_{2}-\mathrm{N}$ level increased. High $\mathrm{NO}_{2}-\mathrm{N}$ values have also indicated organic pollution (Effler et al. 1996). The increase in their biomass during the late summer period was also reported in some other studies (Naselli-Flores and Barone 2000; Borics et al. 2016). Moreover, due to its small volume and surface area, the ratio of benthic habitats is high in Lake Ketence. As a matter of fact, species of this group migrating between the epipelon and the water column prefer small volume basins like temporary ponds, small lakes, etc. (Padisák 1993; Poulicková et al. 2008).

The Chlorophyta division reached its maximum abundance in summer, mostly owing to the excessive growth of T. minimum. High TP and EC levels coupled with high temperature probably contributed to the high abundance of this species during summer (Temponeras et al. 2000; Calijuri et al. 2002) as also confirmed in the RDA. In many studies, it has been found that the small unicellular or colonial unflagellated life forms of Chlorophytes were typical representatives of shallow and nutrient-rich systems (Stoyneva 1998; Borics et al. 2000).

In conclusion, like other shallow lakes in flat lowlands, where land-use activities are high (Leone et al. 2009), Lake Ketence is also more exposed to human influence due to agricultural activities around the lake. Therefore, high nutrient levels and the organic content of the lake have affected the biomass and dominant phytoplankton composition. Although biomass values varied and indicated very good to bad water quality during the studied period, especially the prevalence of chlorophytes such as $T$. minimum which prefer high nutrient and euglenoids such as
E. clavata, E. rubra, P. longicauda, and T. oblonga that grew extremely well under high organic content has confirmed that Lake Ketence is eutrophic and under intense anthropogenic disturbance.

\section{References}

Atıcı T, Obali O, Altındag A, Ahıska S, Aydın D. 2010. The accumulation of heavy metals $(\mathrm{Cd}, \mathrm{Pb}, \mathrm{Hg}, \mathrm{Cr})$ and their state in phytoplanktonic algae and zooplanktonic organisms in Beysehir Lake and Mogan Lake, Turkey. Afr J Biotechnol. 9(4). doi:10.4314/AJB.V9I4

Barone R, Naselli-Flores L. 2003. Distribution and seasonal dynamics of Cryptomonads in Sicilian water bodies. Hydrobiologia. 502(1-3):325-329. doi:10.1007/978-94-017-2666-5

Borics G, Tóthmérész B, Lukács BA, Várbíró G. 2012. Functional groups of phytoplankton shaping diversity of shallow lake ecosystems. In: Salmaso N, NaselliFlores L, Cerasino L, Flaim G, Tolotti M, Padisák J, editors. Phytoplankton responses to human impacts at different scales. Dordrecht: Springer p. 251-262.

Borics G, Tóthmérész B, Grigorszky I, Padisák J, Várbíró G, Szabó S. 2003. Algal assemblage types of boglakes in Hungary and their relation to water chemistry, hydrological conditions and habitat diversity. In: Naselli-Flores L, Padisák J, Bach MF, editors. Phytoplankton and equilibrium concept: the ecology of steady-state assemblages. Dordrecht: Springer $\mathrm{p}$. 145-155.

Borics G, Grigorszky I, Szabo' S, Padisa'k J. 2000. Phytoplankton associations under changing pattern of bottom-up vs. top-down control in a small hypertrophic fishpond in East Hungary. Hydrobiologia.424:79-90. doi:10.1023/A:1003948827254

Borics G, Tóthmérész B, Várbíró G, Grigorszky I, Czébely A, Görgényi J. 2016. Functional phytoplankton distribution in hypertrophic systems across water body size.Hydrobiologia.764(1):81-90. doi:10.1007/s10750-015-2268-3

Brierley B, Carvalho L, Davies S, Krokowski J. 2007. Guidance on the quantitative analysis of phytoplankton in Freshwater Samples. Report to SNIFFER (Project WFD80), Edinburgh.

Calijuri MDC, Dos Santos ACA, Jati S. 2002. Temporal changes in the phytoplankton community structure in a tropical and eutrophic reservoir (Barra Bonita, SPBrazil). J Plankton Res. 24(7):617-634. doi:10.1093/plankt/24.7.617

Carpenter SR, Kitchell JE. (Eds.) 1993. The Trophic Cascade in Lakes. Cambridge: Cambridge University Press.

Clegg MR, Maberly SC, Jones RI. 2007. Behavioral response as a predictor of seasonal depth distribution and vertical niche separation in freshwater phytoplanktonic flagellates. Limnol Oceanogr. 52:441-455. doi:10.4319/10.2007.52.1.0441

Cole JJ, Prairie YT, Caraco NF, McDowell WH, Tranvik LJ, Striegl RG, Duarte CM, Kortelainen P, Downing 
JA, Middelburg JJ, Melack. 2007. Plumbing the global carbon cycle: Integrating inland waters into the terrestrial carbon budget. Ecosystems. 10:172-185. doi:10.1007/s10021-006-9013-8

Cooke GD, Welch EB, Peterson S, Nichols SA. 2016. Restoration and management of lakes and reservoirs. Boca Raton, FL: CRC Press.

Çelik K, Ongun T. 2006. Seasonal dynamics of phytoplankton assemblages across nutrient gradients in shallow hypertrophic Lake Manyas, Turkey. Lake ReservManage. 22(3):250-260. doi:10.1080/07438140609353903

da Costa MRA, Attayde JL, Becker V. 2016. Effects of water level reduction on the dynamics of phytoplankton functional groups in tropical semi-arid shallow lakes. Hydrobiologia. 778(1):75-89. doi:10.1007/s 10750-015-2593-6

Demir AN, Fakığlu Ö, Dural B. 2014. Phytoplankton functional groups provide a quality assessment method by the Q assemblage index in Lake Mogan (Turkey). Turk J Bot. 38:169-179. doi:10.3906/bot-1301-60

EC Parliament and Coincil 2000. Directive of the European Parliament and of the Council 2000/60/EC Establishing a Framework for Community Action in the Field of Water Policy. Luxembourg: European Commission. PE-CONS 3639/1/100 Rev 1.

Effler SW, Brooks CM, Whitehead KA. 1996. Domestic waste inputs of nitrogen and phosphorus to Onondaga Lake, and water quality implications. Lake Reser Manage.12(1):127-140. doi:10.1080/07438149609354003

Elser JJ, Fagan WF, Denno RF, Dean R. Dobberfuhl DR, Folarin A, Huberty A, Interlandi S, Kilham SS, McCauley E, Schulz KL, Siemann EH, Robert W. Sterner RW. 2000. Nutritional constraints in terrestrial and freshwater food webs. Nature. 408:578-580. doi: $10.1038 / 35046058$

European Commission. 2009. European Commission (Joint Research Centre, Institute for Environment and Sustainability) van de Bund, W. (Editor), Water Framework Directive Intercalibration Technical Report. Part 1: Rivers, Italy. EUR 23838 EN/1.

Fakıoğlu Ö, Demir N. 2011. Göllerin ekolojik durumunun değerlendirilmesinde fitoplankton topluluklarının kullanılması. AÜ Çevrebilimleri Dergisi. 3(1):99-105. doi:10.1501/Csaum_0000000048. [in Turkish]

Giroldo D, Vieira AA. 1999. Assimilation and release of $14 \mathrm{C}$ in a tropical strain of Cryptomonas obovata (Cryptophyceae) exposed to several irradiances. J Plank Res. 21(10):1911-1921. doi:10.1093/plankt/21.10.1911

Graham LE, Wilcox LW. 2000. Algae. London: Prentice Hall.

Grigorszky I, Padisa'k J, Borics G, Schitchen C, Borbe'ly, G. 2003. Deep chlorophyll maximum by Ceratium hirundinella (O. F. Mu“ller) Bergh in a shallow oxbow in Hungary. Hydrobiologia. 506-509:209-212. doi:10.1023/B:HYDR.0000008632.57769.19

Guiry MD, Guiry GM. 2020. AlgaeBase. World-wide electronic publication. Galway: National University of
Ireland. [cited 20 December 2020]. Avaible from http://www.algaebase.org.

Harrison JA, Maranger RJ, Alexander RB, Giblin AE, Jacinthe P, Mayorga E, Seitzinger S, Sobota DJ, Wollheim WM. 2009. The regional and global significance of nitrogen removal in lakes and reservoirs. Biogeochem. 93:143-157. doi:10.1007/s10533-008-9272-X

Huber-Pestalozzi G. 1941. Das Phytoplankton des Süßwassers. (Die Binnengewässer, Band XVI). Teil 2. (i) Chrysophyceen, Farblose Flagellaten Heterokonten. Stuttgart: E. Schweizerbart'sche Verlag-sbuchhandlung,.

Huber-Pestalozzi G. 1950. 3 Teil. Cryoptophyceen, Chloromonadien, Peridineen. In: Thienemann A (eds), Das Phytoplankton des Süsswassers. Die Binnengewasser. Stuttgart: E. Schweizerbart'sche Verlagsbuchhhandlung.

Huber-Pestalozzi G. 1961. Das Phytoplankton des Süßwassers. (Die Binnengewässer, Band XVI). Teil 5. Chlorophyceae, Ordnung: Volvocales. Stuttgart: E. Schweizerbart'sche Verlagsbuchhandlung.

Huber-Pestalozzi G. 1962. Das phytoplankton des süsswassers systematik und biologie, 1. Teil, Blaualgen. Stuttgart: E. Schweizerbarth'sche Verlagsbuchhandlung (Nagele u. Obermiller).

Huber-Pestalozzi G. 1969. Das phytoplankton des süsswassers systematik und biologie, 4. Teil, Euglenophycean. Stuttgart: E. Schweizerbarth'sche Verlagsbuchhandlung (Nagele u. Obermiller).

Huber-Pestalozzi, G 1972. Chlorophyceae - Tetrasporales. In: Thieenemann, A. (Ed.) Das phytoplankton des süsswassers. Die Binnengewasser. Stuttgart.

Huber-Pestalozzi G. 1975. Das phytoplankton des süsswassers systematik und biologie, 2. Teil, Diatomeen. Stuttgart: E. Schweizerbarth'sche Verlagsbuchhandlung (Nagele u. Obermiller).

Huber-Pestalozzi G. 1982. Das phytoplankton des süsswassers systematik und biologie, 8 . Teil, 1.Halffe Conjugatophyceae Zygnematales und Desmidiales (excl. Zygnemataceae). Stuttgart: E. Schweizerbarth'sche Verlagsbuchhandlung (Nagele u. Obermiller).

Huber-Pestalozzi G. 1983. Das phytoplankton des süsswassers systematik und biologie, 7. Teil, 1.Halffe Chlorophyceae (Grünalgen) Ordnung: Chlorococcales. Stuttgart: E. Schweizerbarth'sche Verlagsbuchhandlung (Nagele u. Obermiller).

Jeppesen E, Jensen JP, Søndergaard M. 2002. Response of phytoplankton, zooplankton, and fish to reoligotrophication: An 11 year study of 23 Danish lakes. Aquat Ecosyst Health Manag. 5:31-43. doi:10.1080/14634980260199945

John DM, Whitton BA, Brook A.J. 2003. The Freshwater Algal Flora of the British Isles: an identification guide to freshwater and terrestrial algae. The Natural History Museum and The British Phycological Society. Cambridge: Cambridge University Press.

Komarek J, Anagnostidis K. 2008. Cyanoprokaryota, 2. Teil/Part 2: Oscillatoriales, Süswasser Flora von Mitteleuropa (Freshwater Flora of Central Europe). 
Kramer K, Lange-Bertalot H. 1986. Bacillariophyceae. 1. Naviculaceae. In: Süßwasserflora von Mitteleuropa. Stuttgart, New York: Gustav Fischer Verlag, 2/1.

Kramer K, Lange-Bertalot H. 1991a. Bacillariophyceae. 3. Centrales, Fragilariaceae, Eunoticeae. In: Süßwasserflora von Mitteleuropa. Stuttgart, New York: Gustav Fischer Verlag, 2/3.

Kramer K, Lange-Bertalot H. 1991b. Bacillariophyceae. 4. Achnanthaceae, Kritische Ergänzungen zu Navicula (Lineolatae) und Gomphonema Gesamtliteraturverzeichnis. In: Süßwasserflora von Mitteleuropa. Stuttgart, New York: Gustav Fischer Verlag, 2/4.

Kramer K, Lange-Bertalot H. 1999. Bacillariophyceae. 2. Epithemiaceae, Surirellaceae. In: Süßwasserflora von Mitteleuropa. Stuttgart, New York: Gustav Fischer Verlag, 2/2.

Kramer K. 2003. Diatoms of Europe. Volume 4: Cymbopleura, Delicata, Navicymbula, Gomphocymbellopsis, Afrocymbella. ARG, Gantner Verlag KG, Koeltz Scientific Books.

Leone A, Ripa MN, Uricchio V, Dea'k J, Vargay Z. 2009. Vulnerability and risk evaluation of agricultural nitrogen pollution for Hungary's main aquifer using DRASTIC and GLEAMS models. J Environ Manage 90:2969-2978. doi:10.1016/j.jenvman.2007.08.009

Lindenschmidt KE, Chorus I. 1998. The effect of water column mixing on phytoplankton succession, diversity and similarity. J Plank Res. 20(10): 1927-1951. doi:10.1093/plankt/20.10.1927

Longhi ML, Beisner BE. 2009. Environmental factors controlling the vertical distribution of phytoplankton in lakes. J Plank Res. 31:1195-1207. doi:10.1093/plankt/fbp065

Mehner T, Diekmann M, Brämick U, Lemcke R. 2005. Composition of fish communities in German lakes as related to lake morphology, trophic state, shore structure and human-use intensity. Freshw Biol. 50:70-85. doi:10.1111/j.1365-2427.2004.01294.x

Mortensen E, Jeppesen E, Sondergaard M, Kamp Nielsen L. 1992. Nutrient Dynamics and Biological Structure in Shallow Freshwater and Brackish Lakes. Dordrecht: Kluwer Academic Publishers.

Naselli-Flores L. 2000. Phytoplankton assemblages in twenty-one Sicilian reservoirs: Relationships between species composition and environmental factors. Hydrobiologia.424(1):1-11. doi:10.1023/A:1003907124528

Naselli-Flores L, Barone R. 2000. Phytoplankton dynamics and structure: A comparative analysis in natural and man-made water bodies of different trophic state. Hydrobiologia. 438(1/3):65-74. doi:10.1023/A:1004109912119

Nevers MB, Whitman RL. 2010. Lake Monitoring Field Manual. US Geological Survey.

Padisák J, 1993. The influence of different timescale disturbances on the species richness, diversity and equitablity of phytoplankton in shallow lakes. Hydrobiologia. 249:135-156.
Padisák J, Borics G, Fehér G, Grigorszky I, Oldal I, Schmidt A, Zámbóné-Doma Z. 2003. Dominant species, functional assemblages and frequency of equilibrium phases in late summer phytoplankton assemblages in Hungarian small shallow lakes. Hydrobiologia.502(1-3):157-168. doi:10.1023/B:HYDR.0000004278.10887.40

Padisák J, Crossetti LO, Naselli-Flores L. 2009. Use and misuse in the application of the phytoplankton functional classification: A critical review with updates. Hydrobiologia. 621(1):1-19. doi:10.1007/s10750-008-9645-0

Padisák J. 2004. Phytoplankton. In: O’Sullvan PE, Reynolds CS, editors. The Lakes Handbook, Limnology and Limnetic Ecology, Volume 1. Oxford: Blackwell Publishing Company p. 252-308.

Phillips G, Pietila“inen OP, Carvalho L, Solimini A, Lyche Solheim A, Cardoso C. 2008. Chlorophyll-nutrient relationships of different lake types using a large European dataset. Aquat Ecol. 42(2):213-226. doi:10.1007/s10452-008-9180-0

Pollingher U. 1988. Freshwater armored dinoflagellates: growth, reproduction strategies, and population dynamics. In: C. Sandgren (Ed.). Growth and reproductive strategies of freshwater phytoplankton. Cambridge: Cambridge Press p. 134-174.

Poulicková A, Hasler P, Lysáková M, Spears B. 2008. The ecology of freshwater epipelic algae: an update. Phycologia. 47:437-450. doi:10.2216/07-59.1

Reynolds CS. 2006. The Ecology of Phytoplankton (Ecology, Biodiversity and Conservation). Cambridge: Cambridge University Press. doi:10.1017/CBO9780511542145

Reynolds CS. 1993. Scales of disturbance and their role in plankton ecology. Hydrobiologia. 249:157-171.

Reynolds CS, Huszar V. Kruk C, Naselli-Flores L, Melo S. 2002. Towards a functional classification of the freshwater phytoplankton. J Plank Res. 24(5): 417-428. doi:10.1093/plankt/24.5.417

Round FE, Crawford RM, Mann DG. 1990. The Diatoms: Morphology and biology of the genera. Cambridge: Cambridge Universty Press.

Scheffer M. 1998. Ecology of shallow lakes. Population and community biology series 22. Dordrecht: Kluwer Academic Publishers.

Schindler DE, Scheuerell MD. 2002. Habitat coupling in lake ecosystems. Oikos. 98 (2): 177 - 189. doi:10.1034/j.1600-0706.2002.980201.x

Seip KL, Reynolds CS. 1995. Phytoplankton functional attributes along trophic gradient and season. Limonol Oceanogr. 40:589-597.

Sevindik TO, Çelik K. 2014. The Effects of certain physical and chemical variables on the succession of the phytoplankton in the shallow cagis pond (Balıkesir, Turkey). Ekoloji. 23(93):27-35. doi:10.5053/ekoloji.2014.934

Sevindik TO, Tunca H, Gönülol A, Gürsoy N, Küçükkaya ŞN, Kınalı Z. 2017. Phytoplankton dynamics and structure, and ecological status estimation by the Q assemblage index: A comparative analysis in two 
shallow Mediterranean lakes. Turk J Bot. 41:25-36. doi:10.3906/bot-1510-22

Sims PA. 1996. An atlas of britih diatoms. London: Biopress Ltd.

Sondergaard M, Jeppesen E, Jensen JP, Amsinck SL. 2005. Water Framework Directive: Ecological Classification of Danish Lakes. J App Ecol. 42: 616-629. doi:10.1111/j.1365-2664.2005.01040.x

Stevenso RJ, Bothwell ML, Lowe RL, Thorp JH. 1996. Algal ecology: Freshwater benthic ecosystem. Academic press.

Stoyneva MP. 1998. Development of the phytoplankton of the shallow Srebarna Lake (north-eastern Bulgaria) across a trophic gradient. Hydrobiologia. 369: 259-267. doi:10.1023/A:1017015825018

Strickland JDH, Parsons TR. 1972. A Practical Handbook of Seawater Analysis. 2nd ed. Ottawa, Canada: Fisheries Research Board of Canada.

Sun J, Liu D. 2003. Geometric models for calculating cell biovolume and surface area for phytoplankton. J Plank Res. 25(11):1331-1346. doi:10.1093/plankt/fbg096

Taş B, Gönülol A. 2007. An ecologic and taxonomic study on phytoplankton of a shallow lake, Turkey. J Environ Biol. 28(2):439.

Taş Bİ, Gönülol A, Taş E. 2002. A study on the seasonal variation of the phytoplankton of Lake Cernek (Samsun-Turkey). Turkish J Fish Aquat Sci. 2(2): 121-128.

Technicon Industrial Methods. 1977a. Nitrate and Nitrite in Water and Wastewater. No. 158-71. Luton, UK: Technicon.
Technicon Industrial Methods. 1977b. Phosphate and Silicate Analysis in Water and Seawater. No. 253-280 E. Application Note. Luton, UK: Technicon.

Temponeras, M, Kristiansen J, Moustaka-Gouni M. 2000. Seasonal variation in phytoplankton composition and physicalchemical features of the shallow Lake Doïrani, Macedonia, Greece. In: Reynolds CS, Dokulil M, Padisák J, editors. The Trophic Spectrum Revisited. Developments in Hydrobiology, vol 150. Dordrecht: Springer. p. 109-122.

Ter Braak CJF, Smilauer P. 2002. CANOCO reference manual and CanoDraw for Windows user's guide: software for canonical community ordination (version 4.5). Ithaca, NY, USA: Microcomputer Power.

Utermöhl H. 1958. Zur Vervollkommnung der quantitativen Phytoplankton. Methodik Mitt Int VerTheor Angew Limnol. 9:1-38. doi:10.1080/05384680.1958.11904091

Whittington J, Sherman BS, Green D, Oliver RL. 2000. Growth of Ceratium hirundinella in a sub-tropical Australian reservoir: the role of vertical migration. J Plank Res. 22:1025-1045.

Yerli SV, Kıvrak E, Gürbüz H, Manav E, Mangıt F, Türkecan O. 2012. Phytoplankton community, nutrients and chlorophyll a in Lake Mogan (Turkey); with comparison between current and old data. Turkish J Fish Aquat Sci. 12(1):95-104. doi:10.4194/1303-2712-v12_1_12

Y1lmaz N, Güleçal Y. 2012. Phytoplankton community of Terkos Lake and its influent streams, Istanbul, Turkey. Pak J Bot. 44(3):1135-1140. doi:10.13140/2.1.5079.9368 